\title{
"You're fat and not normal!" From Body Image to Decision of Suicide
}

\author{
Lailatul Fitriyah ${ }^{1}$, Tristan Rokhmawan ${ }^{2}$ \\ ${ }^{1}$ Prodi PIAUD Universitas Nurul Jadid Paiton, Indonesia \\ Email: lailatulfitriyah15.lf@gmail.com \\ 2 Prodi PBSI STKIP PGRI Pasuruan, Indonesia \\ Email: tristanrokhmawan19890821@gmail.com
}

\begin{tabular}{l}
\hline \multicolumn{1}{c}{ Artikel info } \\
\hline \\
Artikel history: \\
Received; Oktober-2018 \\
Revised:November-2018 \\
Accepted:Desember-2018 \\
Publish: Maret-2019
\end{tabular}

DOI:

doi.org/10.31960/ ijolec.v1i2.75
Abstract. Bullying has become a highlighted problem in recent years by observers (or researchers) about education, counseling, psychology, and the development of children and adolescents. One of the things that attracts attention is bullying with the theme of form and weight. Physical differences in the body, especially in obese people, are followed by stigma and negative justification. Internalization of stigma and justification leads to cases of oppression, in some cases, even suicide decisions. The author tries to find a network of theoretical and conceptual relationships between body image, diet, bullying, the role of the media, depression, to the decision to commit suicide from various sources and the results of previous studies. In the end, it seems that the habit of mocking and humiliating someone who is overweight, which we often face every day and is considered normal, can be a more serious problem. Being slim and fat is an option, but setting it as a normal standard can bring stereotypical havoc.

Abstrak. Bullying telah menjadi masalah yang disorot dalam beberapa tahun terakhir oleh para pengamat (atau peneliti) tentang pendidikan, konseling, psikologi, dan perkembangan anak-anak dan remaja. Salah satu hal yang menarik perhatian adalah bullying dengan tema bentuk dan berat. Perbedaan fisik dalam tubuh, terutama pada orang gemuk, diikuti oleh stigma dan pembenaran negatif. Internalisasi stigma dan justifikasi mengarah pada kasus-kasus penindasan, dalam beberapa kasus, bahkan hingga keputusan bunuh diri. Penulis mencoba menemukan jaringan hubungan teoretis dan konseptual antara citra tubuh, diet, bullying, peran media, depresi, hingga keputusan untuk melakukan bunuh diri dari berbagai sumber dan hasil penelitian sebelumnya. Pada akhirnya, tampaknya kebiasaan mengejek dan mempermalukan seseorang yang mengalami kegemukan, yang sering kita hadapi setiap hari dan dianggap biasa saja, bisa menjadi masalah yang lebih serius. Menjadi langsing dan gemuk adalah pilihan, tetapi menetapkannya sebagai standar normal dapat membawa malapetaka stereotip.

\section{Coresponden author:}

J1. Raya Talkandang-Batugajah, Dusun Kanal, Desa Talkandang, Kec. Kotaanyar, Kab.Probolinggo Email: lailatulfitriyah15.1f@gmail.com body, dietary,

bullying, media, suicide 


\section{3 | Indonesia Journal of Learning Education and Counseling}

\section{INTRODUCTION}

Angel Green, a 14-year-old girl from Indiana-US, committed suicide by hanging himself on the branch of a tree near the bus stop not far from his school; he committed suicide in front of his friends for often accepting bullying with ridicule as "fat and spotted skin". Ashley Cardona, a 12-year-old girl from Montbello-Colorado-US, committed suicide after much bullying and was called "Gorilla Scarface" for her tall and large body. Brandy Vela, an 18-year-old girl from TexasUS, shot her own head because after being often ridiculed as fat and ugly. Fiona Geraghty, a 14-year-old girl from SommersetUK, suffered from acute bulimia and ended up hanging herself for failing to make her skinny. Brandy Vela, an 18-year-old girl from Texas-US, shot her own chest in the room and in front of her parents after a long period of cyber-bullying on the internet social media for being fat and ugly. Agustina Hermanto or more popularly known as Tina Toonita, an Indonesian artist known for her fat neck movement during her teenage years (and popular because of that character) claimed to have been depressed due to bullying with ridicule of her fat body condition.

Some cases of suicide and depression experienced by some people above certainly slightly open the intent of this literature review article. Negative self-assessment due to a personally assessed body condition that does not fit the general criteria (social or community), in fact, can lead to depression and the decision to end life; suicide. Various research efforts and research conducted by experts to find the relationship between negative body image, depression, and the decision to kill themselves, and various factors causing it.

Various research findings indicate a relationship between body image, attempts to change normal eating patterns, to depression and the decision to commit suicide. A great desire to get a good body shape (in general / social criteria) and low body image, lead to disruption of normal eating habits to problematics of eating disorders and control of poorer body nutrient intake such as bulimia (Paxton \& Franko, 2010; Thompson et al, 1995; Rosen, 1990; Fabian \& Thompson, 1989). Negative body image condition is not only able to make a person interfere with his diet. The amount of verbal or phisical pressure and blasphemy from the people around continue to support increased depression. This case especially in the majority occurs in adolescents. (Himelein \& Thatcher, 2006; Ivarsson et al., 2006; Olivardia et al., 2004; Stice \& Bearman; 2001; Stice et al. 2000; Kostanski \& Gullone, 1998; Rierdan \& Koff; 1997; Orr, et al, 1989; Noles et al., 1985).

Excessive depression due to negative body image is not something trivial. The output of the resulting behavior may vary depending on the mental form of the sufferer. They have considerable possibilities for excessive depression to make it an obsessive anorexia (Cash \& Deagle, 1997; Slade, 1988; Cash, \& Brown, 1987; Garner \& Garfinkel, 1982; Wingate \& Christie, 1978; Garner et al., 1976) or may end up on the decision to end life (Brausch \& Gutierrez, 2009; Cotterill \& Cunliffe, 1997; Collins, 1991; Cotterill, 1981). Over time, cases of bullying with the theme of the body condition continue to grow; from the real world in everyday life to the virtual world.

As far as psychological researchers have developed their assessment, the media has become one of the "favorite scapegoats" for researchers in the field of social psychology. It is no exception when sociopsychological researchers develop the direction of the question to the great role of the media against mindset disorders of body image, eating disorder behavior, bullying to one's appearance, depression resulting from dissatisfaction with body shape, to adolescent decision to commit suicide; all on the role of the media (Fitriyah, 2017, Ferguson, Munoz, Garza, \& Galindo., 2014; Levine \& Murnen, 2009; Hogan \& Strasburger, 2008; Ata, Ludden, \& Lally; 2007; Derenne \& Teresin, 2006; Thompson, J Kevin \& Eric Stice, 2001; Thompson \& Stice, 2001).

\section{METHOD}

This paper was developed with intensive literature review study techniques. The author collects literature on the dynamics of the relationship between the media, body image, distrubed eating pattern, bullying physical appearance, and the despair of life and the decision to commit suicide. Each relationship between these variables is 
comprehensively mapped using various information from the results of previous studies. Then the work of the writer is to compile road maps of how a person can experience depression and the decision to become self-conscious with the background of bulliying and other reinforcing variables such as media roles, body image, and distred eating pattern.

\section{RESULT AND DISCUSSION}

Clearly Known Relationship: The role of the media in shaping perceptions of body image

Media is the most widespread and influential conveyor (carrier) in the sociocultural values of ideal size and shape (McCabe, Butler \& Watt, 2007). The standard of scalable ideal body assessment to measure one's beauty is often shown (or found) in real and subliminal media messages (Groesz, Levine, \& Murnen, 2002; Tiggemann, 2002, in Cash, Morrow, Hrabosky, \& Perry, 2004 ). Media appears to be a major factor affecting the concerns about the ideal body, and the most powerful source of influence on body image perception. This perception is derived from the process of acceptance of values embodied in the exposure of information in the media.

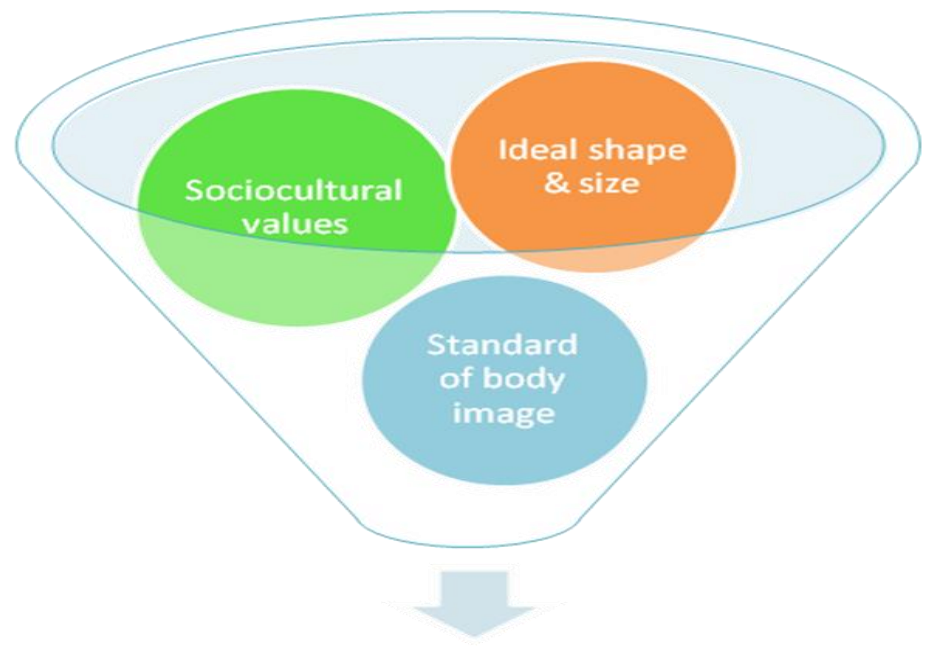

MEDIA INFORMATION

\section{SELF BODY IMAGE}

Figure 1. Media information as the influental conveyor to self body image

Media (ie television, movies, and magazines) is an external force in shaping perceptions about body image. The message (or subliminal message) is absorbed from the real or represented in the media into the mind (Cash, 1997). At a seminar on eating disorders by Christine Nicklaus explains that the process of internalization and the formation of body image in one's perception is as an external cultural influence. Christine Nicklaus further calls this process a "complex comparison". A Complex comparison is based on the motivation behind a person to identify "role model" or "hero" as a symbol of his dreams, personal aspirations, and beliefs about the ideal conditions. People admire role models and aspire to be like them. Comparisons begin with the recognition of, and increased attention given to, personal flaws. This simultaneously becomes an awareness of imperfection in self, compared with the idolized figure. When deficiencies are manifested in comparison, the feelings of inadequacy and failure are overwhelming. As 


\section{5 | Indonesia Journal of Learning Education and Counseling}

people see their role models, performance plays a role in comparison too. Someone may believe that if they look more like their idols, they may be able to act like them; accepted and liked by others (Nicklaus Seminar in Wickman, 2000).

Nicklaus points out that as a message of "ideal heroes" reinforced through the media, there is pressure for people to compare themselves with these athletes, actors, and models. Combined with low self-image and lack of self-confidence, it can certainly degrade one's judgment and can lead one to take drastic steps to change to fit the appearance and behavior of role models, and community norms, in general (Nicklaus Seminar in Wickman , 2000).

The body appearance of a model embodied in the media will affect a teenager's body perception, thereby impacting the evaluation of their appearance. Overweight and obese people in some societies tend to experience greater social harm than physical / health; that's the view that comes up. The attention of viewers is greater on sociallyemotional deficiencies than on health (Brewis, 2011). The sources of information media provide an overview of the standard "ideal body" for teenagers. The standard makes a perception of the body of teenagers. Teenagers can often do unfavorable things to maintain or lead to a standard that they themselves make. The media seems to be a major factor that affects the concerns about the ideal body, and the main source that has the strongest influence on body image perception. The role of this modeling can change adolescent behavior. Information from the media forms a standard for teens about the ideal body.

\section{Clearly Known Relationship: Media and Distrubed Eating Pattern}

Consumer culture and media images that have been inherent in a consumer demographic on a particular social group will in turn create an "identity". Consumer/market identity is the main goal of
The description of the information in the media has a creative and destructive way to adolescents to make adjustments to their social environment standards. The respondents in Becker's (2004) study indicated that they perceive explicit modeling of the characters that exist in television dramas. But besides that, they also perceive weight and body shape, causing them to fall in steps to control body shape in a bad way such as the habit of consuming laxatives in excessive doses (excluding prescription or medical supervision). Their response (teenagers) to television shows to be slim (or thin) is an emerging desire to fulfill the social competition that exists during the transition period of social trend periods. Understanding in depth the images and values that appear in media impressions is the most important way to solve dietary problems and the rest to solving cases of the behavioral disorder in adolescents (Becker, 2004).

Further observing how the media publishes information, we will lead to a multimillion-dollar strategy to billions of dollars invested to market the product through impressions that will be able to influence certain groups that are demographically targeted businesses. An important part of ensuring the success of producers targeting youth groups is to create a "common identity" through advertising. Advertising conditions form a consumer culture. Consumer culture in question is a cultural picture formed by the perception of consumer justification targeted by product advertisers. For example, if an advertisement serves fibrous and low-fat foods as the main menu to be served for breakfast, that is what the advertisers or consumers who target product marketers should do. Otherwise, they (consumers or potential customers) will feel out of the prevailing "culture" in general.

marketing Strategies for some products specifically targeting a particular social group. Giddens (1991) defines identity as a set of concepts built by a social group that 


\section{MEDIAA INFORMATION}

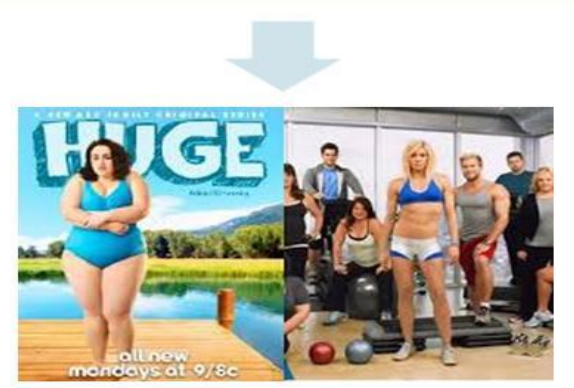

figure / artist representation to body shape

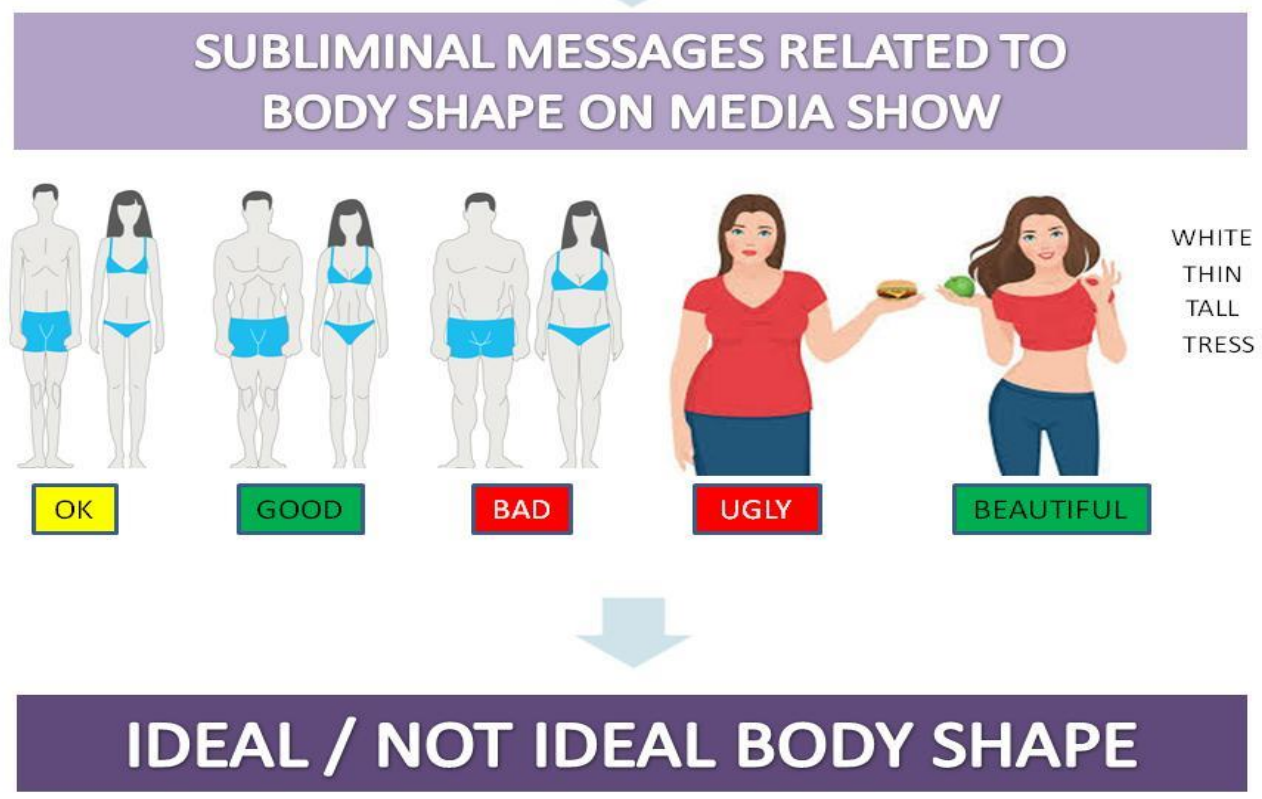

Figure 2. Representation of body image on media

must be met and a reflection in doing every individual activity in it. The identity must be fulfilled so that an individual can be integrated with his group. Identity will help the individual identify "who are they?" And "who is the group?" (Becker, 2004). Increased rates of obesity or overweight in adolescents and the continued strong trend of a skinny and tall ideal indicate that teenagers are in an unfashionable state, and by definition, they will feel disqualified in terms of "ideal-perfect" body conditions. This condition can be very risky especially in adolescent girls. Young women in the pressures of this kind of consumer culture will continue to strive to achieve satisfaction and to look as similar as possible to the models in advertising. They see the media as a guide to self-representation and to become "real teenagers" (Becker, 2004). To achieve the ideal body shape, according to the advertiser's guidance, teenagers will make behavioral changes according to the model in the impression. In this case, advertisers display the form of "cultural normative behavior model" that can be imitated by the intended target audience. Media pressures on consumer culture of products with teenagers' targets displaying thin models will be internalized and in turn, contribute to a feeling of dissatisfaction with post-social comparative conditions and the rest resulting in eating disorders (Becker 2004). Consumer culture that forms an identity of the ideal body can be easily accepted by teenagers and internalized resulting in improper behavior such as disturbed eating patterns.

\section{Clearly Known Relationship: Body Image and Distrubed Eating Pattern}




\section{7 | Indonesia Journal of Learning Education and Counseling}

Body image is a multidimensional concept. In essence, this body image is a perception of the picture of a person's body as a whole, including the appearance of himself. Thus, a person builds himself or body image in many ways, combining input from family, peers, and media pressure. Cash, et al (2004) suggests that body image is a multidimensional construct that includes selfperception and attitudes about a person's physical appearance. The two core aspects of attitudes toward body image include evaluation (eg, body satisfaction) and investment, such as the psychological importance of a person in a place or condition (Hogan, 2010; Cash et al., 2004)

\section{MEDIA INFORMATION}

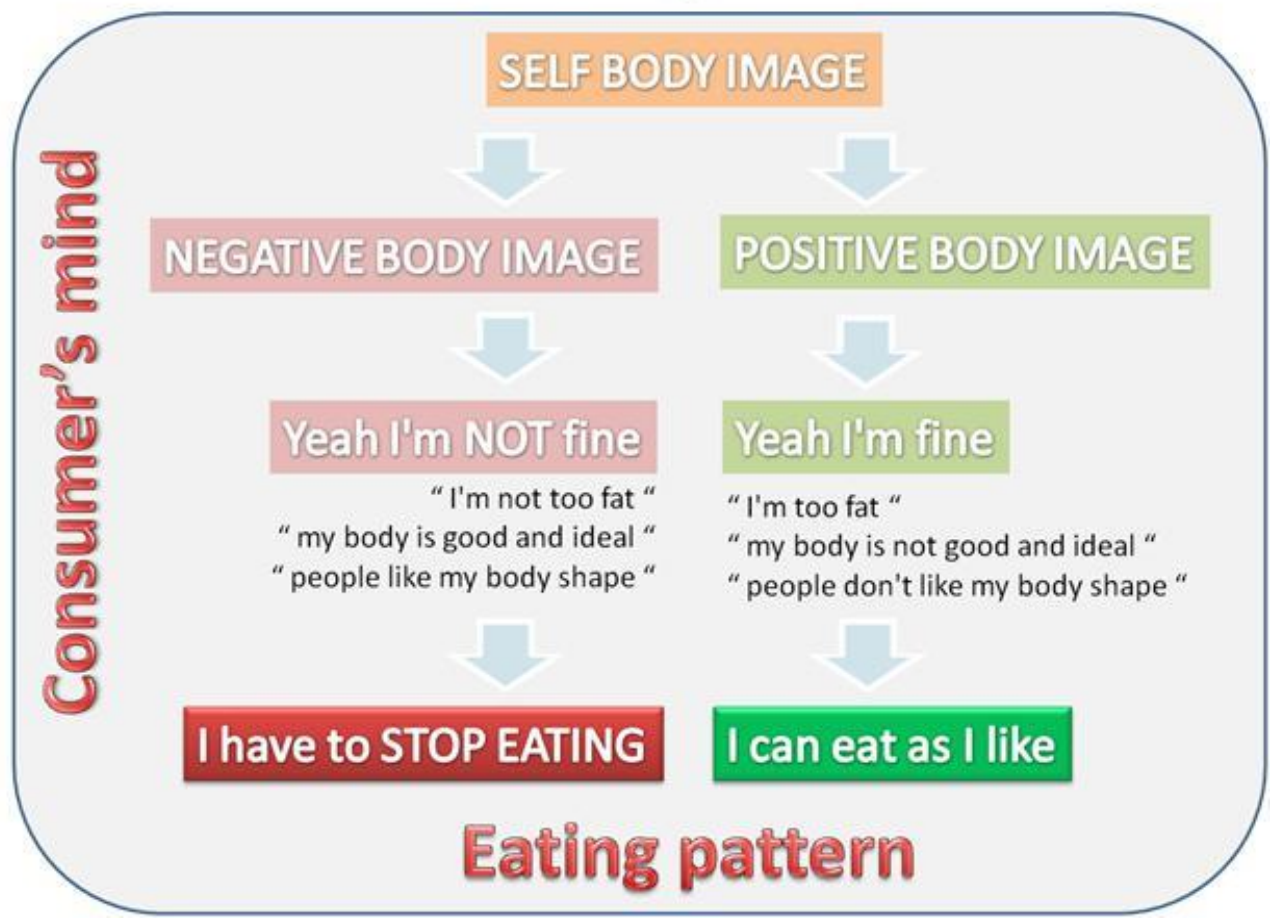

Figure 3. Media information to eating pattern

In adolescence, adolescents experience changes in themselves, especially in the shape of the body. This change is usually not always well received by most teenagers such as changes in size and body shape becomes more fat or thin. This change makes teenagers dissatisfied with the shape and size of the body. From survey data mentioned that almost half (46\%) of girls and $26 \%$ of adolescent boys were dissatisfied with their body shape and size, even only $12 \%$ and $17 \%$, of each reported that teenagers liked their appearance (Hogan et al., 2008).

Body image has a role to disrupt attitudes and eating patterns in adolescents that usually lead to chronic eating disorders. Food irregularities include a variety of eating behaviors that can ultimately lead to more serious eating disorders such as anorexia nervosa, bulimia nervosa, and binge eating (California Department of Public Health.2000).

Dissatisfaction with body shape leads to concepts and perceptions of poor or negative self-body conditions that can be a pressure for teenagers to do things that are not good enough to meet the ideal body concept as they want. The impact of this dissatisfaction leads to changes in adolescent diet such as skipping meals, and eating unhealthy foods; to avoid fats, carbohydrates, sugars, and other ingredients that are allegedly capable of causing obesity. Many teenagers, especially girls, are involved in unhealthy eating behaviors and weight control behaviors (limiting the intake of certain ingredients, laxatives, diuretics or diet pills, and inducing vomiting) because of the 
social emphasis on appearance, image, and power physical attraction (ThøgersenNtoumani et al., 2010; Sáez et al, 2015). Research conducted by Wong et al (2014) shows that sex, weight, dissatisfaction with the body, and expectations about body shape have a significant relationship to the disruption of behavior/attitude to eating in students (in the subjects of research on students in Taiwan). Adolescents with low body image tend to be dissatisfied with their body so that there are various behaviors that interfere with dietary behavior. This arises as an attempt by teenagers to realize a sense of satisfaction with their body shape.

\section{Complex Relationships: Media, Image, and Distrubed Eating Pattern}

Body

Media, body image, and disturbed eating patterns have an inseparable and mutually related relationship (Fitriyah, 2017, Ferguson, Munoz, Garza, \& Galindo., 2014; Levine \& Murnen, 2009; Hogan \& Strasburger, 2008; , Ludden, \& Lally, 2007; Derenne \& Teresin, 2006; Thompson, J Kevin \& Eric Stice, 2001; Thompson \& Stice, 2001). From several sources of research results, the media affect the diet through the mediation of body image. As explained earlier, the media with conventional ideal body-image loads will be a source of knowledge and experience for teenagers to evaluate their body condition. The results of this evaluation embody the shape of body image. High or low body image relates to how the adolescent's evaluation of his or her condition and body, on the basis of the measurement of ideal standards (social standards) presented by the media. A fine body image will not interfere with dietary behavior. But unfortunately, a bad body image will have a negative impact on dietary behavior.

Media information becomes one that can affect the development of body image to a person. Media displays an information that becomes a role model for adolescents to what they idolize. Any picture of body shape displayed through the media is considered to be the common values that adolescent believes to be the general standard it must fulfill. The values and descriptions expressed through the media will serve as a model for teenagers to transport themselves. In turn, the role of modeling is what can be the cause of behavior change in adolescents (Fitriyah, 2018).

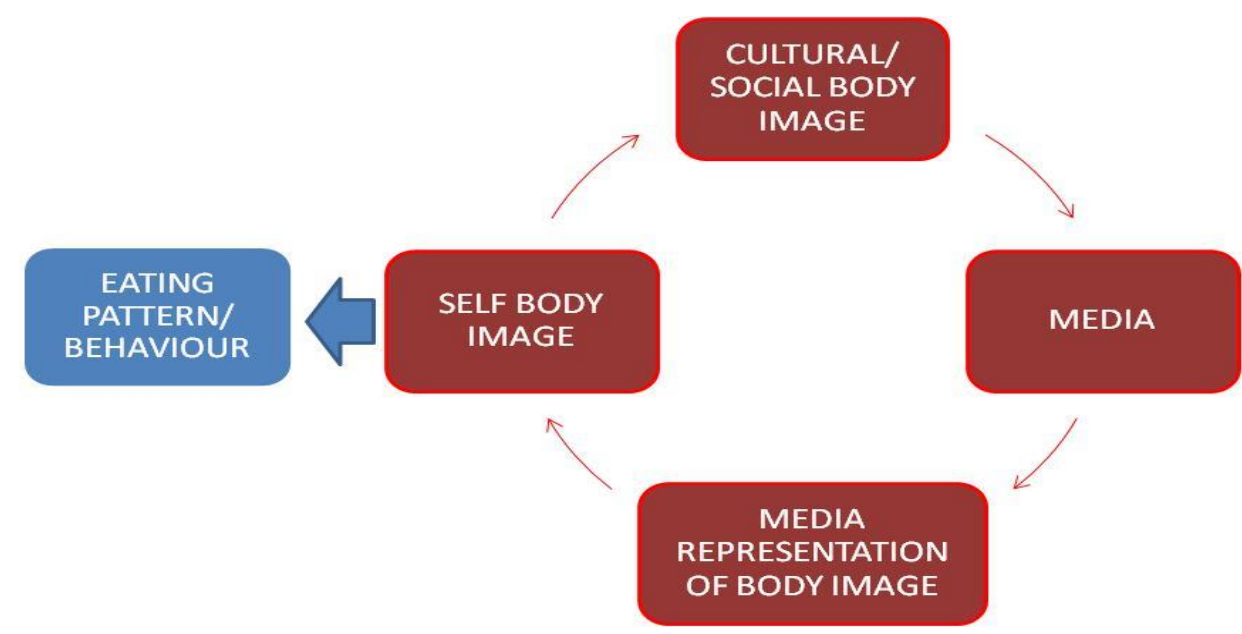

Figure 4. Complex relationship of body image, media, and eating pattern

For the sake of trying to meet the ideal standards, adolescents set up some strategies. One of them is to adjust the diet. Instead of managing a healthy diet, teenagers actually fall into the excessive effort and lead to negative practices in order to get the ideal body. Expectations on ideal body shape have an impact on the wrong eating behavior in adolescents, especially when their body shape is not in accordance with expectations associated with the ideal body standard so that adolescents susceptible to eating disorders. The media becomes the most powerful carrier associated with the body's ideals, size and weight, and dissatisfaction with the body (Fitriyah, 2018). 
Media exposure that contains the subjective value of society about the ideal body image proved successful influence the pattern of adolescent behavior (Fitriyah, 2017). In order to fulfill a similar picture of himself with people in the media, they intervene in the diet. The results in this study are also supported by research from Sinead (2015) which states that the media becomes the most powerful carrier associated with body goals, size and weight, and dissatisfaction with the body. It will eventually deal with other mental health problems such as depression, low selfesteem, and eating disorders.

The direct correlation between media exposure to adolescent tendency to intervene on her behavior is supported by Becker's (2004) research that media pressures on consumer culture of products targeting teenagers who exhibit thin models will be internalized and in turn contribute to feelings of dissatisfaction with the condition of the body post-social comparison process, and the rest lead to eating disorders.

The direct link between media exposure to adolescent tendencies to intervene in their behavior is supported by the literature of research results and literature studies (Hazen et al, 2008; Brinthaup \& Lipka, 2002). Many things are the reasons teenagers to regulate his behavior to adjust to the demands of value in exposure to media information. It has been seen from various reviews and research results that adolescents are very concerned about his position among the people, looking at the views of others around him. To be fully accepted (socially), they make themselves behave and look, transform themselves according to the subjective ideal standard in society. This applies also in terms of body appearance. The media that contains the ideal picture of the body becomes the "good" indicator for teenagers to change their behavior, adjust their bodily condition to the explicit and implied ideal body criteria in the media or standard impressions set by the people around them.

There is a relationship between media and the eating-disordered pattern that is mediated by body image The significant relationship between the media and the dysfunctional eating-pattern that mediated by body image is supported by some research literature, literature study, and conceptual ideas such as Hogan \& Strasburger ( 2008),
Sepúlveda \& Calado. (2012), Ferguson, Munoz, Garza, \& Galindo. (2014), Ata, Ludden, \& Lally (2007), McCabe \& Ricciardelli (2001) and Thompson \& Stice (2001). Media with conventional ideal bodyimage load will be a source of knowledge and experience for teenagers to evaluate their body condition. The results of this evaluation embodies the image of the body High low body image is related to how the evaluation of adolescents will condition themselves and their bodies, on the basis of the measurement of ideal standards presented media.corporate body bad negative impact on dietary behavior. Negative body or negative selfesteem may result in other more serious disorders such as anorexia or bulimia, and it has become a reality especially in the case of adolescent girls (Croll, 2005, Field et al 2001)

Body image significantly serves as a mediator of media influence on distrubed eating. It can be seen from the value of direct influence and the influence of indirect relationship. The media have a direct influence on the eating-the-disturbed pattern, so the body's image play a significant role as mediators. This is because the body image is an important thing that exist in adolescents to determine their self-image that will be tangible on the behavior, among them about dietary behavior. At first the body image builds on the adolescent consciousness of the result of the comparison between her body condition and the ideal standard "set" by society, especially through the media. Teenagers perceive the message in the media as the standard of the ideal body shape. The results of these self-comparisons and standards are manifested in body image. Nonconformity between standard and self condition causes dissatisfaction. Dissatisfaction is what triggers anxiety about self-impairment. To block her anxiety, teenagers begin to manipulate her behavior, changing diet. In other words, there is in fact an important role of the self-value dynamics mechanism that channel the ideal body concept in media, body image, and eating disorders.

This is evidenced by many studies that linked the condition of the body and changes in eating behavior in adolescents (Croll, 2005). Body image is very developed in adolescent life. This is evident in several studies (Croll, 2005: 155). Field, Cheung, Wolf, Herzog, Gortmaker, \& Colditz in 
Exposure to the mass media and weight concerns between girls (Pediatrics 1999) suggest that $50-88 \%$ of girls will think negatively about posture and body size. SmartGirl Speaks in Eating Disease Quick Pages reports (www.smartgirl.org) states that only $33 \%$ of women are mapping that they are in the right weight condition. 58\% wanted weight loss, and only $9 \%$ wanted weight gain.

The direct link between media and distrubed eating has a greater significance rate than the body-mediated relationship. This fact is another important finding in this study, apart from the success of the researchers finding correlations between the three variables studied. Researchers assume that this condition is influenced by the role of other variables, namely the form of selfesteem, which also influence the mechanism of the relationship between media, body image, and distrubed eating (Fitriyah, 2018).

Conditions in the paragraph above occur because not all teenagers show the condition of body image that is too fall (in very troubled condition) even though they (teenagers) indicated to behave bad intervention to diet. The next researcher realizes the possibility of the existence of other variables outside the research is the form of self-value that embodies body image on adolescents studied. The researcher interprets the interrelationships between body images resulting from the evaluation process on the perception of ideal body condition values in the media with both explicit and implicit self-esteem forms defined in the results of Farnham, Greenwald, \& Banaji, 1999 ).

Apparently, many teenagers experience an implicit form of self-esteem, rather than explicit ones. Simply to distinguish it, the individual with self explicitly suggests that he is well aware of the real conditions he is experiencing. For example, a person who realizes that he is not attractive or overweight; and explicitly able to show that he felt problematic or no problem with his condition; so decided to go on a diet or not. In contrast to people with implicit selfesteem, individuals with self-implicit selfesteem do not clearly state their condition, or feel good, even though in reality the results of the examination indicate the behavior of eating disorders. Deeply, within his subconscious, this self-esteem implicit individual feels that he is in trouble and has to go on a diet or lose weight. Therefore, the behavior of manipulating the diet was still done despite states that his body shape is good and fine; something quite strange when people go on a diet but declare that he is fine (Fitriyah, 2018).

If adolescents experience self-esteem regarding explicit body conditions (in the explicit self-esteem state), they are aware of anything related to themselves and their behavior. Teenagers will be very aware and arrive at the evaluation that he was included in the condition less than ideal body standards that are perceived through media information. This awareness is explicit, and the form of appreciation is greatly acknowledged by adolescents. That way, the shape of body image that it has also applied consciously. The behavioral changes that occur in adolescents are based on explicit, clear and conscious grounds.

Conversely, if adolescents experience self-esteem related implicit body conditions, they are unaware of what they feel and do. Adolescents are unaware of the shortcomings (in the statement on the test result), or their weaknesses against the ideal body value criteria. Teens show others that they feel that they are in good body condition and body image. But implicitly, they still have doubts about behaving. Therefore, in the scale of behavioral assessment, the teenager in this case implicitly continues to undergo regulation and intervention on his diet, despite feeling fine. Why does this happen? There are two things that can make the reason. First, the teenager is still unsure of his judgment. They still have an implicit fear, an implicit self-assessment that he is in bad shape. Secondly, this teenager behaves according to the trends in the environment. They see information about daily diets and dietary suggestions in the media as "the latest style of eating trends" to follow. Not because they feel their body is in bad condition so they are on a diet, but only on the pretext of wanting to maintain their body condition, some teens change eating behavior. One of the current trends is to change the food menu with wheat cereal or corn flakes, consuming fruit and unsweetened water (infused/ infusion fruit and water), to the consumption of foods without salt and carbohydrates (carbohydrate diet $\&$ salt diet). 


\section{1 | Indonesia Journal of Learning Education and Counseling}

With an explanation of the type of self-worth above, it becomes natural that teenagers declare themselves well and body conditions ideal, but still manipulate his diet. It is also natural that the rate of correlation between media and feeding behavior without body image mediation is greater than that of the mediated relationship. All because the teenager is not explicitly aware of his own value.

\section{Bad Stereotyping Relationship: Body image and bullying physical appearance}

To discuss more deeply to the bullying relationship of appearance and body image, let us consider some of the usual questions and statements: "are you pregnant?", "Does your dress size increase?", "You look fat" or " you look heavier ". Unconsciously, the curiosity likes to give judgment on the appearance of others, one of them assess body size. Bullying appearance begins with an impression that sounds so trivial but tends to judge other people's body condition like the above examples; problematics one's.

Tomiyama \& Mann (2013) reacted to the question "whether the social judgment of people with fat posture will be able to reduce the fat human population?". This idea begins with the writings of D. Callahan (2012) who want to suppress obesity by creating a social emphasis through the stigma that obese people are socially unacceptable and the general public strongly rejects everyone who is obese. This idea is based on Callahan's findings that many of the overweight people are unaware of his condition. Callahan, therefore, wants to create the discriminatory stigma against obese people. Tomiyama \& Mann replied to Callahan's plan, that he (Callahan) did not bother to make a negative stigma against a fat person. Bad stigma about the fat man has long existed. The strategy against obesity and obesity offered Callahan is clearly without basic treatment and clear health measures.

Bad stigma about obese people, weight-based discrimination and body shape, and humiliation or ridicule against others because the body shape has been around for a long time and is very worrying; even more pervasive and intense in society than racism, sexism, and other forms of bias (Tomiyama \& Mann, 2013; Farrell, 2011). In America, and possibly in Indonesia or other countries, discrimination based on body shape is a form of "legal" discrimination to be expressed to anyone, anywhere, and at any time without having to be ensnared by law; even seems to have become the most favorite bullying theme in youth groups. The strategy against obesity and obesity offered by Callahan can certainly backfire.

Discussing people's views on weight and body shape, people have a bad stigma against the catastrophic body shape of fat. Society in the article Fathi (2011), explained that today's society unwittingly has perpetuated environments that are hostile to obese people. Obesity seems to be a lot of people. Let's see how people describe the fat condition. The "fat observers" and health experts write with many papers that lead to a bad justification of fat people.

A mass media headline writes something worrisome about the condition of fat people as "Coronary Time Bomb", "National Security Threat", or "a ticking time bomb for cardiovascular disease?" (Blake, 2009; Frum, 2010; Logue \& Sattar, 2011 ). Then, the emergence of anti-fat groups that continue to undermine people's minds to make obesity a "scourge" of universal fear (Newsweek, 2010). Anti-fat rhetoric is so widely used in public health and media assessment. Although we also know that obesity can't always be a predictor of ill health or endurance of illness in the future (Campos et al, 2005) and weight loss is not always done and also does not always indicate health (Bacon \& Aphramor, 2011) ). However evidence to reject the negative stigma of obesity is presented, obese people and obesity will remain a scourge for the general public. In fact, mocking other people with obesity may actually make the person more enduring with his body shape as a form of rejection, indifference, or opposition to stigma (Dahl, 2013) 


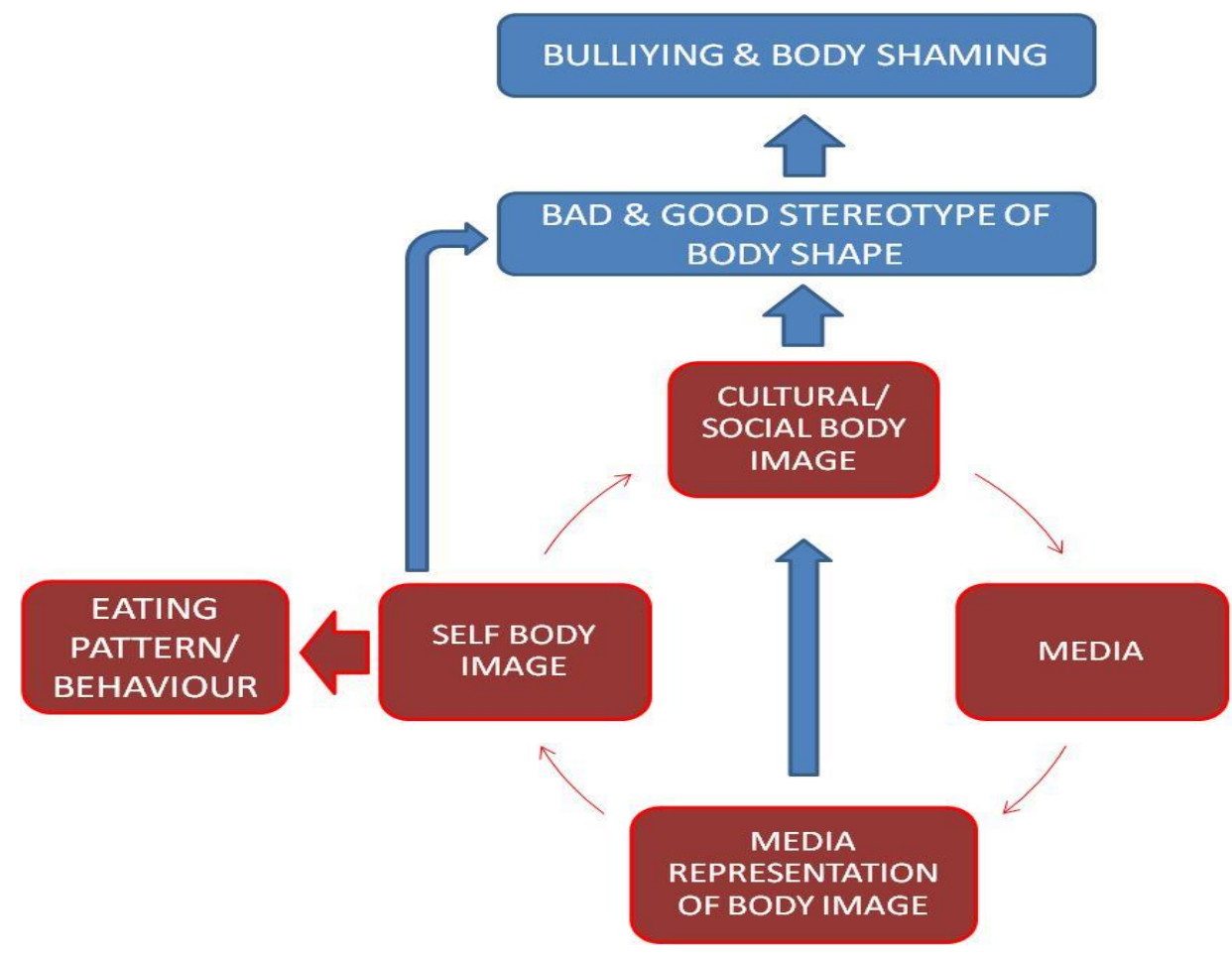

Figure 5. Body image to bullying and body shaming

This stigma underlies self-destruction in people who have a fat body shape (although relatively and subjective) and indicated obesity. People with fat bodies are prone to depression that starts from outside and inside pressure; often from the outside. From the outside, the negative stigma as described above, the continuous bantering of obese people, and the inconsequential analyzes of obese people, that they are lazy and overeating, are the main causes of depression in people with overweight bodies. In fact, we often see those who are fat will be the center of laughs and jokes in TV shows; instilling a stereotype of a fat person as a stupid subject, lazy, poorly educated, and easily mocked, "just like a ball". From within, self-awareness of obese people may be triggered to give a bad judgment on the condition of his own body; disappointment and aggression that arise as a result of dissatisfaction with his own body shape can complement the triggers of depression. However, even this internal factor is born from the stereotyping (external) bad stereotype of the fat body in the minds of the people.

The negative stereotype of a fat body also appears in the form of an aesthetic deficiency assessment. The fat body is not something beautiful and worth seeing. Such is the cruel justification of society which will surely disturb the minds of teenagers and women; we know they are the most wanted to look beautiful and perfect. Studies of teenagers and women show that teenage girls and women suffer from depression twice as strongly as young men because of their dissatisfaction with body shape and the pressure of those around them. The external pressure in the form of mockery makes teen girls and women build a poor selfobjectification of themselves to form a hopelessness depression (depression of despair). Self-anxiety about appearance and thin-ideal internalization also play a major role in this. The phenomenon of obesity is not only a medical one, but also multifaceted problems, gender-related, and socially constructed (Evans, 2010: Harjunen, 2009).

The negative stigma of a fat body is the starting point that begins all the reasons people judge a fat man very hard; they do the bullying, be aware !. The act of bullying with obesity or fatty bodies in schools, for example, mostly done by adolescents, is a collective action on the process of planting the stigma and the judgment of identity against objects that have fat conditions. Referring to the concept of interactionism, the stigma of identity is the embodiment of social processes, constructed and reconstructed in every time 


\section{3 | Indonesia Journal of Learning Education and Counseling}

and opportunity of social interaction.

Bullying often serves as a ritual of selfsatisfaction (for the perpetrators) and social exclusion of bullying objects through the actions of those who construct social thought: "we are normal, and you are not normal". While the negative stigma of a fat person (as an object of intimidation) is to regard him as a social member whose body, shape and size, is not normal. People with fat bodies are stereotyped with such unhealthy, lazy, socially incompetent traits. Such stereotypes affect the various intentions of bullying behavior and may contribute to discriminatory behavior and disturbance of friendship relationships (Thornberg, 2013; Puhl et al., 2015; Greenleaf et al., 2006). Bullying in this fat object becomes an equivalent theme coupled with racism, sexual orientation, religion, skin color, family background, and face shape. Unfortunately, however, no laws or rules, even socially, are capable of suppressing bullying with the theme of body weight and shape.

Bullying themed bodies and obesity can happen anywhere and anytime. Usually occurs in the physical environment: the school as a primary social place of adolescence, home environment, playground, or other learning places outside of school (such as additional tutoring locations). Bullying often occurs in primary school, continues in junior high school, and becomes more intense in high school, and so on (Nansel et al., 2001; Smith, Madsen, and Moody, 1999; Cook et al., 2010). This area is expanded by television broadcasts that showcase bullying scenes and body-themed banter. Then with the development of information media today, the bullying can be said can happen anywhere in every corner of the world where fat human living and being. Thanks to the sophistication of smartphones and internet access, bullying of obese people can happen anytime even when they simply update their status or change their profile photos in social media; then we recognize the term cyberbullying (Cassidy, Jackson, and Brown, 2009; Fred, Murray, and Gilman, 2011; Social media has a wide range, approaches real-world and real-time, and is a source of dynamic data on bullying-related studies. Social media provides a vast space for bullying practice and leaves many traces in it, but the impact can be far beyond to get out of the virtual world; impacting the real world (Xu, Jun, Zhu, \& Bellmore, 2012).

Is the suffering of fat people only limited to mocked and humiliated only in the physical world and in cyberspace? For bullies, they may feel that their task has been completed. But not for victims of bullying. Psychological pressure can not just disappear. Feelings of inferiority, lack of self-esteem, and feeling isolated from the social world will be inherent in the psychology of the bullying victims. It is not a trivial thing when physical stress affects the psyche and obscures the victim's view of the future, breaking his desire to stay alive in life.

\section{Unexpected Relation: Towards The Despair of Life and The Decision to Commit Suicide} Obesity is ultimately not just a physical problem and physical health, but also a psychological problem due to the negative stigma imposed on it. 2 to 7 children who experience bullying due to obesity are experiencing higher health problems, and other problems related to the comfort of life such as a headache, stomach, heart, disturbed sleep patterns, anxiety, to depression. These problems are even able to survive and influence until adulthood. Bullying is defined as a deliberate, repetitive or long-term exposure to negative acts committed by a person or group of persons who consider themselves to be of higher status, and normal, than the victim. Harassment can be expressed as physical, verbal, and social-relational abuse. Previous research on the relationship between overweight and various psychological outcomes, such as depression, suicide attempts, and low self-esteem, suggests that body image and severe dissatisfaction may be an intermediate factor. Body image is someone's impression of itself. or his body. Body image reflects the true body composition, body-related experience, lifelong social response to body appearance and sociocultural values and ideals of the body. In some cultures, for example, the male body is ideally muscled and the female body is emaciated. People who fail - or feel that they are failing - to achieve these collective ideas of an ideal ones may suffer lower self-esteem. But to be an extraordinary case, bullying with the main theme of obesity is usually followed by other themes that complement the banter of bullying victims such as social class, family 
background, skin color, and racism (Brixval et al., 2012).

Hinduja \& Patchin (2014) research 200 children in high school and provides 4 questions: 1. do you feel really sad and desperate for more each day over the past 2 weeks or so so we decide not to do what do you usually do? 2. Have you ever thought seriously about suicide? 3. Have you ever specifically planned to commit suicide? 4. Have you ever deliberately decided to attempt suicide? These questions are related to the results of the examination of the experience of getting bullying over the past several months. As a result, respondents with bullying experience state "Yes" to most of the four questions; and the greater correlated with the longer or heavier bullying cases experienced.

It also found that most forms of bullying received from the environment in the internet world; cyberbullying. A final statement worth reiterating is that those who experience bullying contribute to their increased decision to end life; suicide. The initial cause is the form of bullying, the path to the decision to commit suicide is a form of self-dissatisfaction and life, decreased self-esteem, depression, the emergence of other problems within the immediate environment or the nearest person, and can be exacerbated by the role of psychotropic medication.

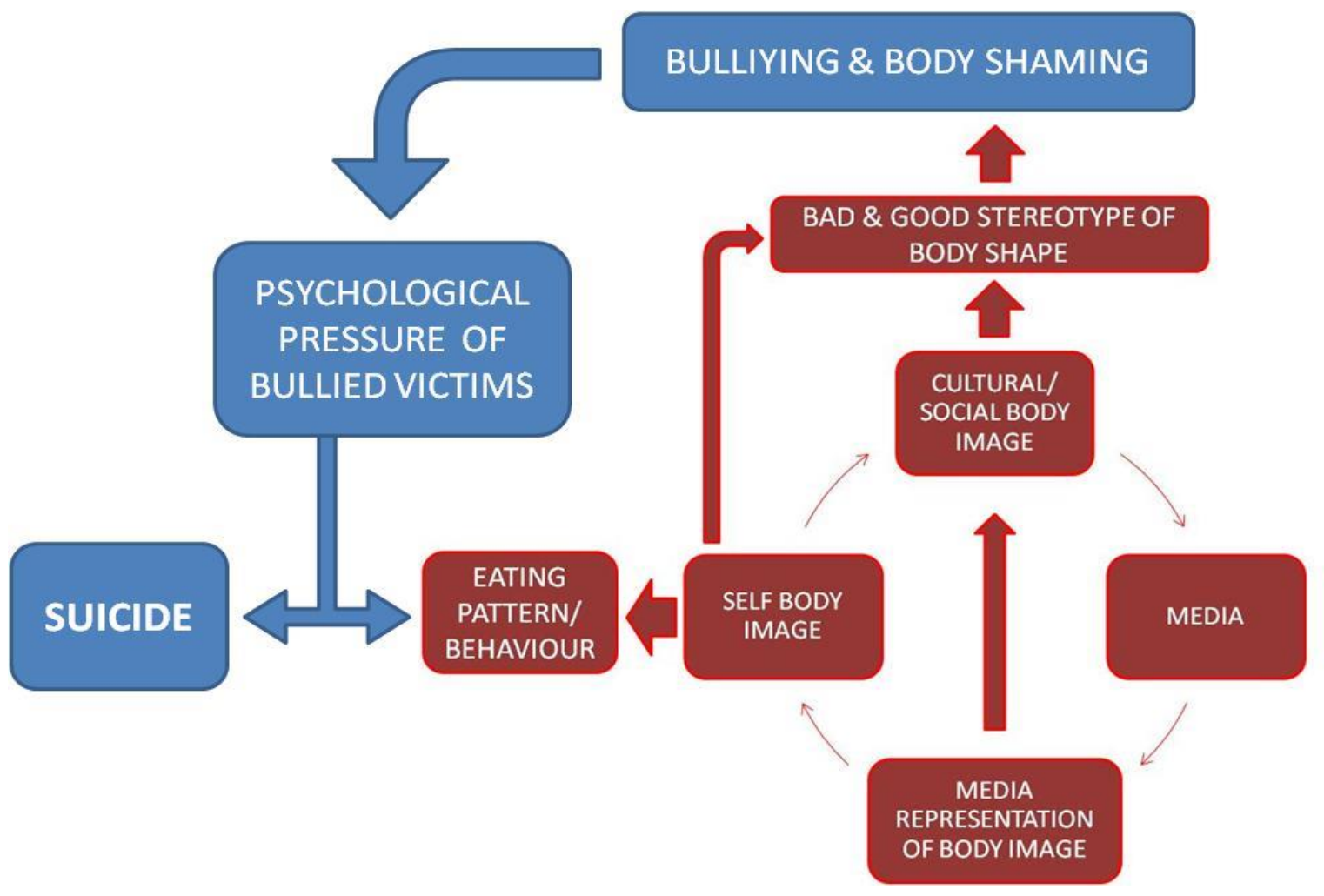

Figure 6. Bullying to psychological pressure and decision to suicide

\section{CONCLUSION AND SUGGEST}

Bullying in a verbal, physical, and social-relational manner with the theme of body weight and physical condition will ultimately lead to mental-psychological destruction, thoughts and feelings for the victim. There's been a lot of case evidence that ended in a decision to commit suicide.
Families and schools should pay attention to this case; may be added also the media that has been proven to be a mediator of the themes of trigger bullying. Families have a great responsibility to embrace the social adjustment power and the confidence of their children through building a strong attachment style in the home environment (Fitriyah, 2013). In addition, the behavior of 


\section{5 | Indonesia Journal of Learning Education and Counseling}

experimenting on teenagers to try to do something dangerous or careless so endanger themselves and their lives, or intentionally want to kill themselves will be avoided (Fitriyah, 2016). Dietary disorders and body image due to the negative stigma against people with obesity conditions eventually became a bigger case because it became an indicator of bad experiences due to bodythemed banter and bullying.

By this, the authors can end this essay by giving some advice to the community to eliminate stigma and ill-treatment in people with body fat. First, by censoring on television shows and other mass media to eliminate hate speech against people with a typical body fat. Especially the actions that showcase the characterization of the character. Second, affirming personal responsibility for everyone, that a person with a fat body has a responsibility for himself and his own life, then mocking a fat person for having gone wrong by making his weight go up will not change anything. Third, stop being fat is something funny! Humiliating overweight people even by showing them as funny does not help fat people to lose weight, but instead puts them under increasing pressure mentally. This is simply to avoid the worse effects of bullying with the theme of weight, body shape, and obesity.

Now, We beg you to reflect on how the death and suicide cases could happen; We have already shown some examples at the beginning of this article. They do not end life unhappily. The "soft banter" they get on every day until it becomes bullying verbally, physically, and socially-relatively plunges them, victims of body-themed bullying, in severe psychological distress. They lead to death without anyone caring, even laughing at it. As with previous obsolete cases, the death and suicide of bullying can never be justified fairly and firmly by law, school, department and ministry, and the communities around the victims; they all seem to keep their mouths and eyes closed to this problem, and such tragedies will continue if none of us will care. We must begin to think that cases of suicide death and physicalthemed bullying do not happen to those around us.

\section{REFERENSI}

Bacon, L., \& Aphramor, L. (2011). Weight science: evaluating the evidence for a paradigm shift. Nutrition journal, 10(1), 9.

Blake, J. (2009). Studies Suggest Overweight Kids are Coronary Time Bombs. Retrieved from http://www.cnn.com/2009/health/11 /12/ moh.kids.cardiac. problem.obesity/

Brausch, A. M., \& Gutierrez, P. M. (2009). The role of body image and disordered eating as risk factors for depression and suicidal ideation in adolescents. Suicide and Life-Threatening Behavior, 39(1), 5871.

Brixval, C. S., Rayce, S. L., Rasmussen, M., Holstein, B. E., \& Due, P. (2011). Overweight, body image and bullyingan epidemiological study of 11-to 15years olds. The European Journal of Public Health, 22(1), 126-130.

Callahan, D. (2013). Obesity: Chasing an elusive epidemic. Hastings Center Report, 43(1), 34-40.

Campos, P., Saguy, A., Ernsberger, P., Oliver, E., \& Gaesser, G. (2005). The epidemiology of overweight and obesity: public health crisis or moral panic?. International journal of epidemiology, 35(1), 55-60.

Cash, T. F., \& Brown, T. A. (1987). Body image in anorexia nervosa and bulimia nervosa: A review of the literature. Behavior modification, 11(4), 487-521.

Cash, T. F., \& Deagle, E. A. (1997). The nature and extent of body-image disturbances in anorexia nervosa and bulimia nervosa: A meta-analysis. International Journal of Eating Disorders, 22(2), 107-126.

Collins, M. E. (1991). Body figure perceptions and preferences among preadolescent children. International Journal of eating disorders, 10(2), 199-208. 
Cook, C. R., Williams, K. R., Guerra, N. G., Kim, T. E., \& Sadek, S. (2010). Predictors of bullying and victimization in childhood and adolescence: A metaanalytic investigation. School psychology quarterly, 25(2), 65.

Cotterill, J. A. (1981). Dermatological non-disease: a common and potentially fatal disturbance of cutaneous body image. British Journal of Dermatology, 104(6), 611-619.

Cotterill, J. A., \& Cunliffe, W. J. (1997). Suicide in dermatological patients. British Journal of Dermatology, 137(2), 246-250.

Dahl, Melissa. (2013). 'Fat shaming' actually increases risk of becoming or staying obese, new study says. Retrieved from https://med.fsu.edu/uploads/files/...

Derenne, J. L., \& Beresin, E. V. (2006). Body image, media, and eating disorders. Academic psychiatry, 30(3), 257-261.

Evans, M. A. (2010). Unattainable beauty: an analysis of the role of body shame and self-objectification in hopelessness depression among college-age women. University of Massachusetts Boston.

Fabian, L. J., \& Thompson, J. K. (1989). Body image and eating disturbance in young females. International Journal of Eating Disorders, 8(1), 63-74.

Farrell, A. E. (2011). Fat shame: Stigma and the fat body in American culture. NYU Press.

Fathi, F. (2011). Why Weight Matters: Addressing Body Shaming in the Social Justice Community. In The mission of the Columbia Social Work Review is to provide a forum for the exchange of innovative ideas that integrate social work practice, education, research, and theory from the perspec-tive of social work students. Founded by students at Columbia University School of Social Work in 2003 as the Columbia Uni(p. 23).
Fitriyah, L. (2013). Hubungan Antara Tendensi Gaya Kelekatan dengan Penyesuaian Sosial Pada Siswa SMP Islam Paiton Yang Tinggal Di Pesantren. Skripsi Jurusan PsikologiFakultas Pendidikan Psikologi UM.

Fitriyah, L. (2016). Eksperimentasi sebagai Pintu Perilaku Beresiko pada Remaja.

Fitriyah, 1. (2017, March 31). Effect Of Media To Disordered Eating Mediated By Body Image On Adolescents. http://doi.org/10.17605/OSF.IO/2JT CD

Fitriyah, lailatul. (2018, March 29). Effect Of Media To Disordered Eating Mediated By Body Image On Adolescents. http://doi.org/10.17605/ OSF.IO/NRUV6

Fredstrom, B. K., Adams, R. E., \& Gilman, R. (2011). Electronic and school-based victimization: Unique contexts for adjustment difficulties during adolescence. Journal of youth and adolescence, 40(4), 405-415.

Frum, D. (2010). Why Obesity is a National Security Threat. Retrieved from http://www.cnn.com/2010/opinion/1 2/06/frum.obesity.military/

Garner, D. M., \& Garfinkel, P. E. (1982). Body image in anorexia nervosa: Measurement, theory and clinical implications. The International Journal of Psychiatry in Medicine, 11(3), 263284.

Garner, D. M., Garfinkel, P. E., Stancer, H. C., \& Moldofsky, H. (1976). Body image disturbances in anorexia nervosa and obesity. Psychosomatic medicine.

Greenleaf, C., Chambliss, H., Rhea, D. J., Martin, S. B., \& Morrow, J. R. (2006). Weight stereotypes and behavioral intentions toward thin and fat peers among White and Hispanic adolescents. Journal of Adolescent Health, 39(4), 546-552.

Harjunen, H. (2009). Women and fat: Approaches to the social study of 


\section{7 | Indonesia Journal of Learning Education and Counseling}

fatness. Jyväskylä studies in education, psychology and social research 379.

Himelein, M. J., \& Thatcher, S. S. (2006). Depression and body image among women with polycystic ovary syndrome. Journal of health psychology, 11(4), 613-625.

Hinduja, S., \& Patchin, J. W. (2014). Bullying beyond the schoolyard: Preventing and responding to cyberbullying. Corwin Press.

Ivarsson, T., Svalander, P., Litlere, O., \& Nevonen, L. (2006). Weight concerns, body image, depression and anxiety in Swedish adolescents. Eating behaviors, 7(2), 161-175.

Jackson, M., Cassidy, W., \& Brown, K. (2009). Out of the mouth of babes: Students' voice their opinions on cyberbullying. Long Island Education Review, 8(2), 24-30.

Kostanski, M., \& Gullone, E. (1998). Adolescent body image dissatisfaction: Relationships with self-esteem, anxiety, and depression controlling for body mass. The Journal of Child Psychology and Psychiatry and Allied Disciplines, 39(2), 255-262.

Levine, M. P., \& Murnen, S. K. (2009). "Everybody knows that mass media are/are not [pick one] a cause of eating disorders": A critical review of evidence for a causal link between media, negative body image, and disordered eating in females. Journal of Social and Clinical Psychology, 28(1), 9-42.

Logue, J., \& Sattar, N. (2011). Childhood obesity: a ticking time bomb for cardiovascular disease?. Clinical pharmacology \& Therapeutics, 90(1), 174-178.

Nansel, T. R., Overpeck, M., Pilla, R. S., Ruan, W. J., Simons-Morton, B., \& Scheidt, P. (2001). Bullying behaviors among US youth: Prevalence and association with psychosocial adjustment. Jama, 285(16), 2094-2100.
Newsweek. (2010). Feedback: Michelle Obama and Obesity. Retrieved from http://www.newsweek.com/2010/03/ 24/feed-your-children-well.html

Noles, S. W., Cash, T. F., \& Winstead, B. A. (1985). Body image, physical attractiveness, and depression. Journal of consulting and clinical psychology, 53(1), 88.

Olivardia, R., Pope Jr, H. G., Borowiecki III, J. J., \& Cohane, G. H. (2004). Biceps and body image: the relationship between muscularity and self-esteem, depression, and eating disorder symptoms. Psychology of men \& masculinity, 5(2), 112.

Orr, D. A., Reznikoff, M., \& Smith, G. M. (1989). Body image, self-esteem, and depression in burn-injured adolescents and young adults. The Journal of burn care \& rehabilitation, 10(5), 454-461.

Paxton, S. J., \& Franko, D. L. (2010). Body image and eating disorders. Using technology to support evidence-based behavioral health practices: A clinician's guide, 151-168.

Puhl, R. M., Latner, J. D., O'brien, K., Luedicke, J., Forhan, M., \& Danielsdottir, S. (2016). Cross-national perspectives about weight-based bullying in youth: nature, extent and remedies. Pediatric obesity, 11(4), 241250.

Rierdan, J., \& Koff, E. (1997). Weight, weight-related aspects of body image, and depression in early adolescent girls. Adolescence, 32(127), 615.

Rosen, J. C. (1990). Body-image disturbances in eating disorders. In T. F. Cash \& T. Pruzinsky (Eds.), Body images: Development, deviance, and change (pp. 190-214). New York, NY, US: Guilford Press.

Slade, P. D. (1988). Body image in anorexia nervosa. The British Journal of Psychiatry, 153(Suppl 2), 20-22.

Smith, P. K., Madsen, K. C., \& Moody, J. C. (1999). What causes the age decline in 
reports of being bullied at school? Towards a developmental analysis of risks of being bullied. Educational Research, 41(3), 267-285.

Stice, E., \& Bearman, S. K. (2001). Bodyimage and eating disturbances prospectively predict increases in depressive symptoms in adolescent girls: a growth curve analysis. Developmental psychology, 37(5), 597.

Stice, E., Hayward, C., Cameron, R. P., Killen, J. D., \& Taylor, C. B. (2000). Body-image and eating disturbances predict onset of depression among female adolescents: a longitudinal study. Journal of abnormal psychology, 109(3), 438.

Thompson, J. K., \& Stice, E. (2001). Thinideal internalization: Mounting evidence for a new risk factor for bodyimage disturbance and eating pathology. Current directions in psychological science, 10(5), 181-183.

Thompson, J. K., Coovert, M. D., Richards, K. J., Johnson, S., \& Cattarin, J. (1995). Development of body image, eating disturbance, and general psychological functioning in female adolescents: Covariance structure modeling and longitudinal investigations. International Journal of Eating Disorders, 18(3), 221-236.

Thornberg, R. (2015). School bullying as a collective action: Stigma processes and identity struggling. Children \& Society, 29(4), 310-320.
Tomiyama, A. J., \& Mann, T. (2013). If shaming reduced obesity, there would be no fat people. Hastings Center Report, 43(3), 4-5.

Vandebosch, H., \& Van Cleemput, K. (2009). Cyberbullying among youngsters: Profiles of bullies and victims. New media \& society, 11(8), 1349-1371.

Wang, J., Iannotti, R. J., \& Nansel, T. R. (2009). School bullying among adolescents in the United States: Physical, verbal, relational, and cyber. Journal of Adolescent health, 45(4), 368-375.

Wingate, B. A., \& Christie, M. J. (1978). Ego strength and body image in anorexia nervosa. Journal of Psychosomatic Research, 22(3), 201-204.

Xu, J. M., Jun, K. S., Zhu, X., \& Bellmore, A. (2012, June). Learning from bullying traces in social media. In Proceedings of the 2012 conference of the North American chapter of the association for computational linguistics: Human language technologies (pp. 656-666). Association for Computational Linguistics.

Zervios, James. (2015). Ban The F Word Movement. Retrieved from http://www. obesityaction.org/ wpcontent/uploads/05-Ban-F-Word.pdf 